\title{
IMPACT OF SEDIMENT FORMED IN BIOGAS PRODUCTION ON PRODUCTIVITY OF CROPS AND ECOLOGIC CHARACTER OF PRODUCTION OF ONION FOR CHIVES'
}

Waclaw Romaniuk ${ }^{\mathrm{a}^{*}}$, Victor Polishchuk ${ }^{\mathrm{b}}$, Andrzej Marczuk ${ }^{\mathrm{c}}$, Liudmyla Titova ${ }^{\mathrm{b}}$, Ivan Rogovskii ${ }^{\mathrm{b}}$, Kinga Borek ${ }^{\mathrm{a}}$

a Institute of Technology and Life Sciences in Falenty, Warsaw Branch, Poland

${ }^{\mathrm{b}}$ National University of Life and Environmental Sciences, Kiev, Ukraine

${ }^{c}$ Department of Agricultural and Transport Machines, University of Life Sciences in Lublin, Poland

"Corresponding author: e-mail: w.romaniuk@itp.edu.pl

\begin{tabular}{|c|c|}
\hline ARTICLE INFO & ABSTRACT \\
\hline $\begin{array}{l}\text { Article history: } \\
\text { Received: January } 2018 \\
\text { Received in the revised form: } \\
\text { February } 2018 \\
\text { Accepted: February } 2018\end{array}$ & $\begin{array}{l}\text { The solid fraction, according to many researches, is an effective organic } \\
\text { fertilizer, the activity of which is at the level of mineral fertilizers and even } \\
\text { exceeds their effectiveness, while the use of the liquid fraction does not } \\
\text { always give positive results. In the article the optimal concentration of the } \\
\text { liquid fraction in water solution for fertilization during cultivation of onion }\end{array}$ \\
\hline $\begin{array}{l}\text { Key words: } \\
\text { biogas, } \\
\text { biogas plant, } \\
\text { biosludge, } \\
\text { slugde from biogas plant, } \\
\text { organic ferilizers, } \\
\text { onion for chives, } \\
\text { productivity, } \\
\text { nitrogen, } \\
\text { concentration }\end{array}$ & $\begin{array}{l}\text { obtained at the thermophilic fermentation }\left(50^{\circ} \mathrm{C}\right) \text { of cattle manure in the } \\
\text { laboratory institution which operated at the periodical regime of loading. } \\
\text { Fermentation lasted } 25 \text { days. Seven variants of plant feeding were as- } \\
\text { sessed: clean water (control), mineral fertilizers (solution of ammonium } \\
\text { nitrate in water in the concentration of } 1: 25) \text {, unsolved liquid biofuel } \\
\text { fraction and mixture of liquid fraction from the postferment with water in } \\
\text { concentrations of } 1: 10,1: 50,1: 100,1: 500 \text {. It was determined that the } \\
\text { highest efficiency was observed in case of fertilization of plants with the } \\
\text { mixture of liquid fraction from postferment with concentration of } 1: 500 \text {. } \\
\text { Along with the increase of liquid fraction concentration and fertilization of } \\
\text { plants with water solution of mineral fertilizers, onion productivity } \\
\text { dropped slightly. Fertilization of plants with the liquid fraction from } \\
\text { postferment resulted in fractional dying of plants and reduction of efficien- } \\
\text { cy. The crop control of nitrogen content proved that in case of every day } \\
\text { watering of onion with clean water and mixture of liquid fraction with } \\
\text { water concentration of } 1: 100-1: 500 \text { did not exceed the maximum admissi- } \\
\text { ble concentration which is } 800 \mathrm{mg} \cdot \mathrm{kg}^{-1} \text {. Thus, in case of onion cultivation } \\
\text { for chives, taking into consideration the crop growth and low nitrogen } \\
\text { content, it is recommended to use the mixture of liquid fraction with water } \\
\text { of } 1: 500 \text { concentration. }\end{array}$ \\
\hline
\end{tabular}

1 Исследования выполненные в рамках проекта "Междисциплинарные исследования по повышению энергоэффективности и увеличению доли возобновляемых источников энергии в энергетическом балансе польского сельского хозяйства", Номер контракта BIOSTRATEG1/269056/5/NCBR/2015 11.08.2015 год, финансируемый по Национальный Центр Исследований и Разработок в рамках программы BIOSTRATEG1. 
W. Romaniuk, V. Polishchuk, A. Marczuk, L. Titova, I. Rogovskii, K. Borek

\section{Постановка проблемы}

Навоз, который является отходом производства продукции животноводства, как правило, применяется для повышения плодородия почвы в качестве органического удобрения. Вместе с тем, в первый год внесения свежего навоза крупного рогатого скота (КРС) растения используют $30-40 \%$ фосфора, $60-70 \%$ калия и лишь около $18 \%$ азота, содержащегося в нем. Полное усвоение растениями питательных веществ навоза происходит в течение трех лет. При разложении навоза одновременно с минерализацией азота, фосфора и серы, не менее $70 \%$ углерода органического вещества превращается в диоксид углерода. С одной стороны, это улучшает питание растений через фотосинтез, однако значительное количество углекислого газа, не потребленного растениями, попадает в верхние слои атмосферы, усиливая парниковый эффект.

Поэтому перед внесением свежего навоза в почву его необходимо подготовить. При компостировании образуется перегной, питательные вещества которого усваиваются гораздо лучше. Однако сам процесс компостирования занимает достаточно длительное время, при этом не решается проблема выбросов в атмосферу углекислого газа. Другим способом подготовки навоза к более полному усвоению его питательных веществ растениями является его метановое сбраживание. При этом образуется ценное органическое удобрение, которое в разных источниках называется по-разному: биошлам, шлам биогазовых производств, ефлюент, биогазовый осадок, биоудобренте, дигестат, дигестатная пульпа и т.д. Также значительная часть углерода, которая в других случаях участвовала в возникновении парникового углекислого газа, превращается в энергетически ценный газ метан, который в смеси с углекислым газом образует биогаз.

\section{Анализ последних исследований}

В работах (Mirel и др., 2012; Tambone и др., 2010), указано, что шлам биогазовых производств, в том числе и полученный после анаэробного сбраживания осадка сточных вод, благодаря высокому содержанию питательных веществ (N, P., K) может быть использован в качестве органического удобрения для сельскохозяйственных земель. W. Baader, T. Dohne и M. Brenndorfer объяснили механизм образования такого качественного органического удобрения в процессе метанового сбраживания отходов, согласно которому в процессе брожения аммиак выделяется из органических азотистых соединений и вместе с соединениями фосфора и калия, имеющимися в субстрате, а также образующимися в результате разложения, и превращает переброженную массу в богатое питательными веществами органического удобрения. Кроме того, в зависимости от степени сбраживания, уменьшается содержание углерода по сравнению с его содержанием в исходном субстрате. Обусловленное этим уменьшение соотношения. $\mathrm{C} / \mathrm{N}$ оказывается благоприятным при использовании шлама в качестве удобрения. Кроме того, во время метанового разложения органических веществ происходит разложение органических соединений, ответственных за наличие неприятных запахов в начальном субстрате. Поэтому шлам биогазовых производств, как правило, не имеет 
Impact of sediment formed...

того запаха, который характерен для начального продукта до его метанового сбраживания.

Степень разложения органического вещества (биоконверсия) бесподстилочного навоза зависит от экспозиции. По мнению В.И. Кравчука, В.С. Таргони и В.П. Клименко, максимальная степень биоконверсии органического вещества 53\% (техническое сбраживание) достигается лишь при долгосрочной экспозиции и на практике не используется. Лучшие органические удобрения при метановом сбраживании в мезофильном режиме получаются при степени биоконверсии органического вещества 30-33\%. Для достижения такого уровня биоконверсии органической массы в проточных реакторах полного смешивания необходима экспозиция 20-22 суток. При этом следует иметь в виду, что в установках непрерывного и квазинепрерывного действия часть субстрата может выйти из установки в не полностю переработанном виде. В установках периодического действия средняя продолжительность брожения сырья при психрофильном температурном режиме составляет 30-40 суток и более, при мезофильном режиме - в пределах 10-20 суток, при термофильном - в пределах 5-10 суток.

В работе (Sahlstrom, 2003) отмечается, что шлам биогазовых производств можно использовать как удобрение на сельскохозяйственных угодьях. Однако известно, что он содержит патогенные бактерии, такие как сальмонелла и другие микроорганизмы, которые могут представлять опасность для здоровья, как для людей, так и для животных. Поэтому этим риском не следует пренебрегать. Так, в работе (Kuusik и др., 2017) был проведен микробиологический анализ шлама биогазовых производств, который показал наличие Salmonella spp. как в лабораторных реакторах, так и в образцах, взятых из полномасштабных биогазовых установок. Исследование возможности использования шлама биогазовых производств после сбраживания осадка сточных вод, навоза КРС и органической фракции твердых бытовых отходов в мезофильном режиме проведено в работе (Bonetta и др., 2014). Микробиологический анализ шлама биогазовых производств показал общее присутствие сальмонеллы и недостаточное снижение индикаторных организмов в процессе метанового сбраживания. Присутствие патогенов (например, Listeria monocytogenes) в некоторых образцах показало важность микробиологической оценки качества шлама биогазовых производств для изучения возможных рисков для здоровья потребителей. Вместе с тем, в другом исследовании, изложенном в работе (Pampillon-Gonzalez и др., 2017), в шламе биогазовых производств после сбраживания навоза свиней не было обнаружено никаких видов сальмонеллы, Shigella spp. или жизнеспособных яиц гельминтов, но было наличие фекальных колиформ (бактерий группы кишечной палочки).

В любом случае шлам биогазовых производств перед использованием в качестве органических удобрений нужно обезвредить. Также необходимо наличие микробиологической оценки качества биошлама перед его внесением в качестве органического удобрения для предотвращения возможных рисков для здоровья потребителей.

Гигиенический эффект анаэробного брожения, как считают W. Baader, T. Dohne и M. Brenndorfer, обусловливается, прежде всего, тепловым воздействием в течение определенного отрезка времени. Для уничтожения отдельных возбудителей болезней 
W. Romaniuk, V. Polishchuk, A. Marczuk, L. Titova, I. Rogovskii, K. Borek

нужно в каждом конкретном случае определенная минимальная температура и минимальная продолжительность их пребывания при этой температуре. Чтобы гарантировать полное уничтожение вегетативных форм бактериальных возбудителей инфекционных заболеваний, в установках периодического действия при температуре брожения около $30^{\circ}$ для этого необходимо более 30 суток. Более эффективное действие в течение меньшего срока пребывания массы в реакторе (12-20 суток) достигается только при температуре брожения выше $50^{\circ} \mathrm{C}$. Однако абсолютно надежного обеззараживания ожидать не следует, так как всегда существует риск, что незначительное количество микробов сохранит свою жизнеспособность и сможет послужить источником инфекции. Что касается установок непрерывного и квазинепрерывного действия, то мы рискуем тем, что небольшие порции субстрата выйдут из реактора быстрее заданного времени. Таким образом, возникает опасность, что патогенным организмам удастся избежать необходимого для их уничтожения теплового воздействия. Надежного обеззараживания не гарантирует ни один вариант анаэробного сбраживания.

Кроме патогенных микроорганизмов, в шламе биогазовых производств могут присутствовать тяжелые металлы и другие вредные вещества. В работе (Pecharaply и др., 2007) указано, что в шламе биогазовых производств после сбраживания сточных вод пивоваренного завода тяжелые металлы, такие как хром и медь находятся на

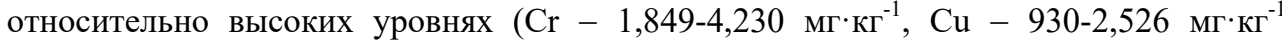
высушенного осадка). Однако металлы присутствуют как связанные с органическим веществом, не растворимые и не доступные. Такой шлам биогазовых производств можно безопасно вносить в почву как источник питательных веществ для растений. В работе (Kuusik и др., 2017) указано, что концентрация тяжелых металлов не превышает максимальных уровней, разрешенных министром окружающей среды Эстонии, а в исследовании (Рecharaply и др., 2007) указано, что концентрация тяжелых металлов в шламе биогазовых производств после сбраживания навоза свиней не превзошли верхние пределы, установленные Агентством по охране окружающей среды США (ЕРА). Вместе с тем, в (Bonetta и др., 2014) отмечено, что в нескольких образцах шлама биогазовых производств после сбраживания осадка сточных вод, навоза КРС и органической фракции твердых бытовых отходов в мезофильном режиме, содержание $\mathrm{Cu}, \mathrm{Ni}$ и $\mathrm{Zn}$ превышали максимально допустимую концентрацию, предусмотренную в итальянском законодательстве. Это указывает на возможное загрязнение окружающей среды, если шлам биогазовых производств будет использоваться для сельскохозяйственных целей. Однако авторы считают эту работу только как предварительное исследование для оценки возможного использования биогазового дигестата.

В работе (Наі и др., 2017) было проведено исследование содержания вредных веществ, таких как медь, кадмий, трибутилтин (tributyltin), дибутилтин (dibutyltin), перфтороктан сульфонат, 952 полулетучих органических соединений и 89 антибиотиков, в четырех биогазовых установках на острове Кюсю (Япония). Установлено, что концентрация загрязняющих веществ в исследуемых образцах указывает на то, что они могут быть безопасными для сельскохозяйственных целей.

Десять биогазовых установок в Финляндии были проанализированы в работе $\mathrm{Su}-$ ominen и др., 2014) на десять опасных органических соединений или составных групп: полихлорированные дибензо-п-диоксины и фураны (polychlorinated dibenzo-p- 
Impact of sediment formed...

dioxins and furans, $\mathrm{PCDD} / \mathrm{Fs}$ )), полихлоридные бифенилы (polychlorinated biphenyls, PCB (7)), полиароматические углероды (polyaromatic hydrocarbons, PAH (16)), бис (2этилгексил) фталат (bis-2-ethylhexyl phthalate, DEHP), перфторированные алкильные соединения (perfluorinated alkyl compounds, PFCs), линейные алкилбензолсульфонаты (linear alkylbenzene sulfonates, LASs), нонилфенол и нонилфенол этоксилаты (nonylphenols and nonylphenol ethoxylates, NP+NPE0s), полиброминадный дифенильный эфир (polybrominated diphenyl ethers, PBDEs), гексабромоцидододекан (hexabromocydododecane, HBCD) и тетрабромбисфенол A (tetrabromobisphenol A, TBPA). Сбраживаемое сырье было разделено на шесть групп: муниципальный осадок сточных вод, муниципальные биоотходы, жиры, побочные продукты пищевой промышленности, навоз животных и просроченные пищевые продукты животного происхождения с розничной торговли. Не выявлено четкой связи между видами сырья для метанового сбраживания и концентрациями опасных органических соединений в шламе биогазовых производств. Установлено, что только PBDEs и PFCs могут накапливаться в сельскохозяйственных почвах после многократного внесения шлама биогазовых производств, содержащих данные соединения, в качестве органических удобрений. Для других соединений, включенных в это исследование, сельскохозяйственное использование шлама биогазовых производств не вызывает риски для безопасности выращенных пищевых продуктов.

Шлам биогазовых производств можно непосредственно вносить в поле в качестве органических удобрений, или можно разделить его на твердую и жидкую фракции. В таком виде шлам более удобен для хранения и транспортировки. Так, в работе (Bayle и др., 2016) отмечается, что шлам биогазовых производств является хорошим органическим удобрением, но его качество может быть улучшено путем разделения на фракции или компостирования. А в работе (Al Seadi, 2013) указано, что распространенной технологией является сепарация твердой и жидкой средой с использованием винтовых сепараторов и декантерных центрифуг; дальнейшие обработки и технологии могут применяться для стабилизации твердой фракции или дальнейшей переработки жидкой фракции.

В работе (Czekala и др., 2017) проведено исследование использования твердой фракции шлама биогазовых производств для дальнейшего компостирования, которое для уничтожения патогенной микрофлоры определенное время проводилось при температуре $70^{\circ} \mathrm{C}$. Общее время компостирования составляло 51 день. В работе утверждается, что компостирование твердой фракции может решить вопрос использования шлама биогазовых производств. В (Stefaniuk и др., 2015) проанализирована возможность использования остатков после производства биогаза в качестве органических удобрений. Исследования проводились без сепарации и после разделения на твердую и жидкую фракции. Отмечается, что особенно негативное влияние на тестируемые организмы было отмечено для жидкой фракции после сепарации. Во многих случаях шлам биогазовых производств без разделения также оказывал неблагоприятное воздействие на тестируемые организмы. Жидкая фракция после разделения и неразделенные материалы вызывали торможение роста корней L. sativum и S. alba на уровне $17,42-100 \%$ и $30,5-100 \%$ соответственно, а также ингибирование размножения F. candida в диапазоне от $68,89 \%$ до $100 \%$. В большинстве случаев экотоксикологический эффект для тестируемых организмов не 
W. Romaniuk, V. Polishchuk, A. Marczuk, L. Titova, I. Rogovskii, K. Borek

наблюдался для твердой фракции. Твердая фракция после разделения проявляла наиболее благоприятные свойства.

В работе (Pecharaply и др., 2007), кроме исследования производства биогаза, также проводилось исследование использования шлама биогазовых производств после сбраживания сточных вод пивоваренного завода. Установлена высокая концентрации питательных веществ: азота - 3,2-4, 2\%, фосфора - 1,9-3,2\%, калия 0,95-0,96\%. Использовать шлам биогазовых производств от сбраживания остатков производства ликероводочной продукции (послеспиртовой барды) в качестве органического азотного удобрения предлагалось в (Nicoletto и др., 2014). Полевой эксперимент проводился на весенне-летних сортах салата. Было установлено, что использование шлама биогазовых производств в качестве органических азотных удобрений не осуществляет негативного влияния на рост растений, сохраняя качественные аспекты без изменений. Содержание нитратов был ниже жестких ограничений, установленных регламентом ЕС. В работе (Pampillon-Gonzalez и др., 2017) был сделан вывод, что при использовании шлама биогазовых производств в качестве органических удобрений при выращивании пшеницы, он был богатым питательными веществами при низком содержанием тяжелых металлов и патогенов. При этом биошлам и не влиял на выбросы метана и углекислого газа при внесении в грунт, засеянный пшеницей, но увеличивал выброс диоксида азота.

Как показано в (Odlare и др., 2011), чтобы исследовать потенциальные риски и выгоды от использования шлама биогазовых производств в сельском хозяйстве, в центральной Швеции был проведен восьмилетний полевой эксперимент, в ходе которого сравнивалось его влияние в качестве удобрений с влиянием минеральных удобрений. Исследовались урожайность сельскохозяйственных культур и химические и микробиологические свойства почв. Основной вывод из полевого эксперимента заключался в том, что урожайность культур при внесении шлама биогазовых производств была почти такой же высокой, как и при внесении минеральных удобрений. Кроме того, после применения шлама биогазовых производств были улучшены несколько важных микробиологических свойств почвы, таких как грунтовое дыхание, потенциальное окисление аммония и минерализация азота. При использовании шлама биогазовых производств в качестве удобрений не обнаружено никаких негативных эффектов. Шестнадцать лет проводился полевой эксперимент (Odlare и др., 2015), во время которого в сельскохозяйственные угодья в качестве органического удобрения вносился шлам биогазовых производств после сбраживания осадка сточных вод. Установлено, что после 16 лет появлялись лишь небольшие различия в поглощении растениями металлов и органических загрязнителей. Кроме того, шлам биогазовых производств хорошо зарекомендовал себя в качестве удобрения. Однако в работе отмечается, что эффективность минеральных удобрений была выше.

В работе (Nabel и др., 2017) рассмотрен замкнутый цикл использования питательных веществ при выращивании энергетической культуры Sida hermaphrodita, используя в качестве органического удобрения шлам биогазовых производств. В качестве контроля применялось подпитки культуры минеральными удобрениями. Установлено, что применение в качестве органического удобрения шлама биогазовых производств на бедных почвах улучшает их плодородие за счет 
Impact of sediment formed...

повышенного содержания углерода в почве, способности удерживать влагу и базального (микробного) дыхание почвы.

Результаты исследование влияние на урожайность ячменя шлама биогазовых производств после сбраживания травы, бобовых культур и смеси травы и бобовых культур приведены в работе (Muller-Stover и др., 2016). В процессе эксперимента было установлено, что все испытуемые шламы увеличили биомассу ячменя на 40$170 \%$, что в значительной степени можно сравнить с минеральным азотом. Однако применение шлама, образовавшегося при ферментации чистой травы, привело к худшему росту растений и более неустойчивому содержанию минеральных веществ почвы по сравнению с другими исследуемыми шламами.

В работе (Rozylo и др., 2016) проводились исследования влияния шлама биогазовых производств и минеральных удобрений на урожай пшеницы, а также на качество пищевых продуктов из нее. Установлено, что как после использования шлама биогазовых производств, так и минеральных удобрений, урожай зерна пшеницы был увеличен по сравнению с выращиванием пшеницы без удобрения. Зерна пшеницы, выращенные после удобрения, как только шламом биогазовых производств, так и шламом биогазовых производств и минеральными удобрениями, содержали гораздо больше белка и мокрой клейковины по сравнению с отсутствием удобрения и стандартного удобрения только минеральными удобрениями. Изученные условия статистически не влияли на содержание крахмала. Было установлено, что по сравнению с выращиванием на традиционных минеральных удобрениях, выращивание пшеницы на шламе биогазовых производств положительно влияет на антирадикальную активность пшеницы. Сделан вывод, что шлам биогазовых производств может быть альтернативой обычным минеральным удобрениям без каких-либо ухудшений, а в некоторых случаях и с улучшением урожайности и качества пшеницы. Также исследование влияния шлама биогазовых производств при удобрении пшеницы проводилось в работе (Garg и др., 2005). Индекс площади листьев, плотность корневой системы и урожайность зерна пшеницы были выше на участках, которые удобрялись шламом биогазовых производств, по сравнению с участками которые не были удобрены.

Результаты исследований влияния биошлама органической части твердых бытовых отходов на урожайность овса по сравнению с влиянием компоста и минеральных удобрений описаны в работе (Svensson и др., 2004). Каждое удобрение

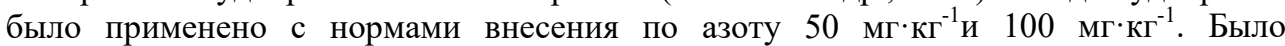
установлено, что при внесении чистых минеральных удобрений отмечалась наибольшая урожайность, а при контроле без внесения удобрений - наименьшая урожайность. Комбинация применения органических удобрений (компоста и биошлама) и минеральных удобрений вызвала большую урожайность по сравнению с применением только органического удобрения. При внесении биошлама в качестве удобрения отмечалась высшая урожайность и качество зерна, чем при внесении компоста.

Эффективность использования шлама биогазовых производств после сбраживания навоза КРС по сравнению с эффективностью использования коммерческих органических и минеральных удобрений при выращивании сафлора исследовалось в работе (Kocar, 2008). Была установлена более высокая урожайность сафлора при использовании шлама биогазовых производств. 
W. Romaniuk, V. Polishchuk, A. Marczuk, L. Titova, I. Rogovskii, K. Borek

Сравнение эффективности применения биошлама органических бытовых отходов, компоста и куриного помета при выращивании лука-порея было проведено в работе (Båth и Rämert, 1999). Все эксперименты были проведены на четырех типах почвы (песчаная почва, два типа суглинков и глинистая почва). После 168 дней инкубации содержание неорганического азота от общего азота составляло 40-60\% для биошлама, $15 \%$ для компоста и 20-30\% для куриного помета. Только при использовании куриного помета чистая азотная минерализация была достигнута во всех четырех почвах в конце инкубации. Растениями лука-порея было использовано от $5 \%$ до 20\% азота биошлама, 1\% азота компоста и $6 \%$ азота куриного помета. А внесение биошлама анаэробного сбраживания отходов обработки тунца и твердых бытовых отходов при выращивании кукурузы на острове Тутуйла (Американское Самоа) вызвало увеличение урожая прямо пропорционально увеличению нормы внесения (Rivard и др., 1995).

В работе (Montemurro и др., 2008) сравнивалось влияние шлама биогазовых производств и минеральных удобрений на урожайность кормовых культур: люцерны и ежи сборной. Было установлено, что при выращивании люцерны не было обнаружено существенных различий суммарного сухого веса растений при использовании указанных удобрений, тогда как средняя производительность ежи сборной при внесении шлама биогазовых производств была выше, в первый год на $41,3 \%$, а во второй год - на $23,0 \%$.

Влияние шлама биогазовых производств на урожайность растений, поглощение азота, микробную биомассу почвы, грунтовые микромицеты и корневые микроорганизмы при культивировании итальянского райграса изучалось в работе (Wentzel и Joergensen, 2016). Было установлено, что внесение в качестве органического удобрения твердой фракции шлама биогазовых производств увеличили среднюю общую надземную растительную биомассу на $66 \%$, а несепарированного шлама биогазовых производств - на $35 \%$ по сравнению с контролем без внесения удобрений. Среднее значение поглощения азота растениями увеличилась при использовании твердой фракции шлама биогазовых производств на $166 \%$, несепарированного шлама биогазовых производств - на 65\% по сравнению с выращиванием итальянского райграса без удобрения. Влияние применения отсепарированной твердой фракции и несепарированного шлама биогазовых производств на грунтовые микробные показатели были аналогичными, за исключением нижней биомассы микромицетов. В отличие от твердой фракции, невотсепарированный шлам биогазовых производств значительно увеличивал микробную биомассу почвы (примерно на 25\%) по сравнению с контролем без внесения удобрений.

В работе (Simeckova и др., 2016) рассматривалось применения компоста и шлама биогазовых производств в качестве потенциальных альтернативных органических источников азота, которые могут использоваться без негативного влияния на свойства почвы. Самый высокий уровень использования азота был обнаружен в вариантах, где были применено совместное внесение шлама биогазовых производств

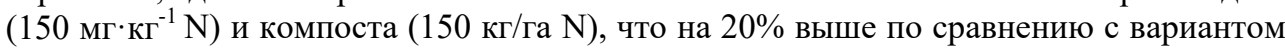
контроля (без удобрений) и на $35 \%$ - с вариантом внесения минерального азота. В работе сделан вывод, что применение шлама биогазовых производств произвело 
Impact of sediment formed...

положительное влияние на развитие биомассы растений, а применение компоста - на повышение плодородия почв.

В Бразилии, в Федеральном университете Парана (UFPR), были проведены исследования влияния шлама биогазовых производств, полученного при сбраживании маниоки, на развитие растений катрана (crambe) (Neves и дp, 2017). В пяти повторах применялось пять вариантов со следующими дозами внесения: 0, 40, 80, 120 и 160 кг/га. Оценивались следующие параметры: конечная высота растения, диаметр стебля, количество побегов, биомасса корней, масса семян и содержание

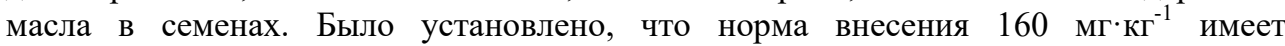
наибольшее влияние на развитие растений, поскольку все измеренные параметры достигли самых высоких значений. Это исследование показало, что биоудобрение, полученное путем анаэробного сбраживания маниоки, может быть использовано в качестве альтернативы минеральным удобрениям при культивировании crambe.

Итак, шлам биогазовых производств можно использовать в качестве органического удобрения для повышения урожайности сельскохозяйственных культур (Mirel и др., 2012; Tambone и др., 2010). Эффективность его как удобрения, по мнению W. Baader, T. Dohne и M. Brenndorfer, зависит от степени разложения органических веществ, что, в свою очередь, определяется режимом загрузки и сбраживания (периодического, непрерывного или квазинепрерывного ), экспозицией сбраживания, температурным режимом, видом сырья и т.п. Однако биошлам может содержать патогенные микроорганизмы, такие как Salmonella (Sahlstrom, 2003; Kuusik и др., 2017; Bonetta и др., 2014), Listeria monocytogenes (Bonetta и др., 2014), кишечную палочку (Pampillon-Gonzalez и др., 2017). В некоторых исследованиях (Pampillon-Gonzalez и др., 2017) отмечается отсутствие Salmonella, Shigella, жизнеспособных яиц гельминтов. В любом случае шлам биогазовых производств перед использованием в качестве органических удобрений нужно обезвредить. Наиболее действенным способом обезвреживания является повышение температурного режима метантенка. Однако и он не дает полной гарантии уничтожения болезнетворных микроорганизмов. Также отмечается наличие в шламе биогазовых производств тяжелых металлов, хрома и меди (Kuusik и др., 2017; Bonetta и др., 2014; Pampillon-Gonzalez и др., 2017; Pecharaply и др., 2007), никеля, цинка (Bonetta и др., 2014), других вредных веществ антибиотиков (Наі и др., 2017; Suominen и др., 2014). В большинстве случаев их концентрация не вызывает рисков безопасности выращенных продуктов питания, однако в (Bonetta и др., 2014) отмечается повышенная концентрация в выращенных продуктах меди, никеля, цинка.

Шлам биогазовых производств можно непосредственно вносить в поле в качестве органических удобрений (Stefaniuk и др., 2015), или можно разделить его на твердую и жидкую фракции (Al Seadi, 2013; Stefaniuk и др., 2015). Твердая фракция может быть подвергнута компостированию (Czekala и др., 2017).

Проводились исследования применения шлама биогазовых производств для повышения урожайности сельскохозяйственных культур (Odlare и др., 2011; Odlare и др., 2015), пшеницы (Pampillon-Gonzalez и др., 2017; Rozylo и др., 2016; Garg и др., 2005), ячменя (Muller-Stover и др., 2016), овса (Svensson и др., 2004), кукурузы (Rivard и др., 1995), сиды обоеполой (Nabel и др., 2017), сафлора (Kocar, 2008), люцерны и ежи сборной (Montemurro и др., 2008), итальянского райграса (Wentzel и Joergensen, 2016), весенне-летних сортов салата (Nicoletto и др., 2014), лука-порея 
W. Romaniuk, V. Polishchuk, A. Marczuk, L. Titova, I. Rogovskii, K. Borek

(Båth и Rämert, 1999) crambe (Neves и др., 2017). Шлам биогазовых производств использовался после сбраживания осадка сточных вод (Mirel и др., 2012; Tambone и др., 2010; Kuusik и др., 2017; Bonetta и др., 2014; Suominen и др., 2014), сточных вод пивоваренного завода (Рecharaply и др., 2007), послеспиртовой барды (Nicoletto и др., 2014), навоза животных (Suominen и др., 2014), навоза КРС (Kocar, 2008), навоза свиней (Pampillon-Gonzalez и др., 2017), травы, бобовых культур и их смеси (MullerStover и др., 2016), маниоки (Neves и др., 2017), отходов переработки тунца (Rivard и др., 1995), некондиционных пищевых продуктов животного происхождения (Suominen и др., 2014). Для исследований также использовались биошлам твердых бытовых отходов (Svensson и др., 2004; Båth и Rämert, 1999; Rivard и др., 1995).

Установлено, что в большинстве случаев использование шлама биогазовых производств вызвало повышение урожайности без сепарации (Pampillon-Gonzalez и др., 2017; Nicoletto и др., 2014; Nabel и др., 2017; Muller-Stover и др., 2016; Rozylo и др., 2016; Garg и др., 2005; Kocar, 2008; Båth и Rämert, 1999; Rivard и др., 1995; Montemurro и др., 2008; Wentzel и Joergensen, 2016; Simeckova и др., 2016; Neves и др., 2017), при использовании твердой фракции (Stefaniuk и др., 2015; Wentzel и Joergensen, 2016), лишь в работе (Rozylo и др., 2016) отмечается ухудшение урожайности после использования жидкой фракции и после использования биошлама без сепарации.

Указано на более высокую эффективность твердой фракции шлама биогазовых производства по сравнению с жидкой фракцией и с неотсепарированным биошламом (Wentzel и Joergensen, 2016).

Отмечается, что использование биошлама твердых бытовых отходов обеспечивает меньшую урожайность, чем использование минеральных удобрений, но большую, чем при использовании компоста (Svensson и др., 2004).

Вместе с тем, в перечисленных исследованиях в большинстве случаев не указаны рекомендуемые нормы внесения как неотсепарированного биошлама, так и твердой и жидкой фракций, для повышения урожайности культур, а также не проведена оценка содержания нитратов в полученном урожае. Кроме того, согласно анализу проведенных исследований установлено, что твердая фракция биогазовых производств эффективно повышает урожайность сельскохозяйственных культур, тогда как использование жидкой фракции не всегда дает положительные результаты. Однако в этих работах не указано, какие именно концентрации жидкой фракции шлама биогазовых производств давали отрицательные результаты, а какие положительные.

Поэтому задачей наших исследований является установление оптимальной концентрации жидкой фракции шлама биогазовых производств в водном растворе для подкормки растений (лука на перо) при почвенном выращивании с целью получения максимального урожая с минимальным содержанием нитратов.

\section{Результаты исследований}

Установление оптимальной концентрации жидкой фракции шлама биогазовых производств в водном растворе для подкормки растений проводилось при почвенном выращивании лука на перо. Для получения зеленого пера использовался репчатый 
Impact of sediment formed...

лук диаметром 2,5-3 см. Чтобы ускорить прорастание лука посадочный материал замачивался на 12 ч. в воде с температурой $35-38^{\circ} \mathrm{C}$.

Исследование осуществлялось на лабораторно-экспериментальной установке (рис. 1), которая находится в учебно-научной лаборатории биоконверсий в агропромышленном комплексе Национального университета биоресурсов и природопользования Украины.

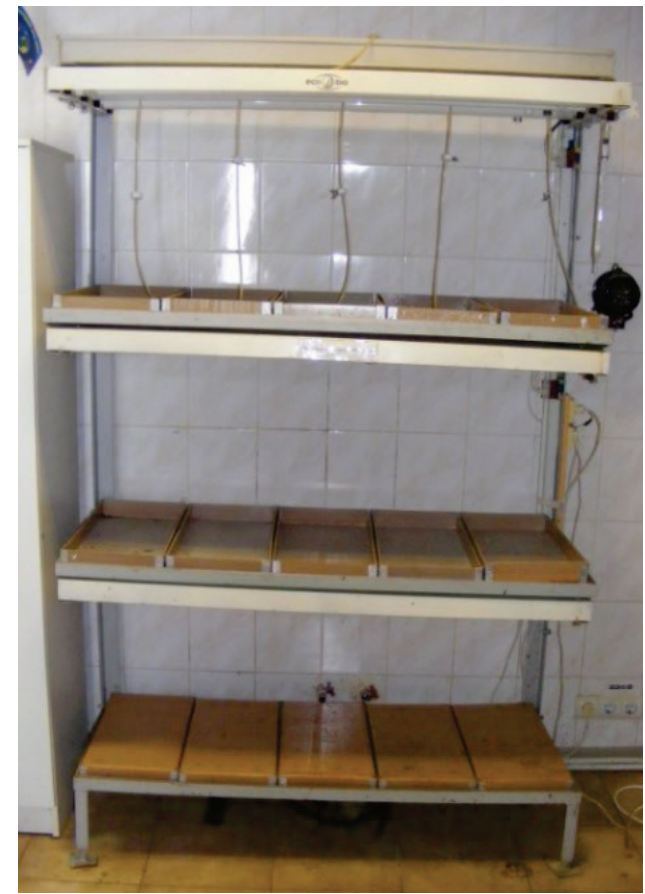

Рисунок 1. Лабораторно-экспериментальная установка, на которой проводилась выгонка лука на перо

Установка состояла из рамы, на которую устанавливался поддон, в который помещались пластиковые ящики (рис. 2) с грунтом. В дне ящиков были сделаны отверстия для стока избытка жидкости. Над ящиками размещались люминесцентные лампы дневного света для досвечивания рассады (рис. 3).

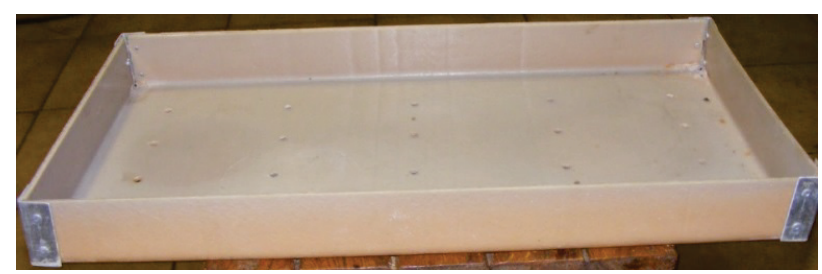

Рисунок 2. Пластиковый ящик, в котором осуществлялось выращивания растений 
W. Romaniuk, V. Polishchuk, A. Marczuk, L. Titova, I. Rogovskii, K. Borek

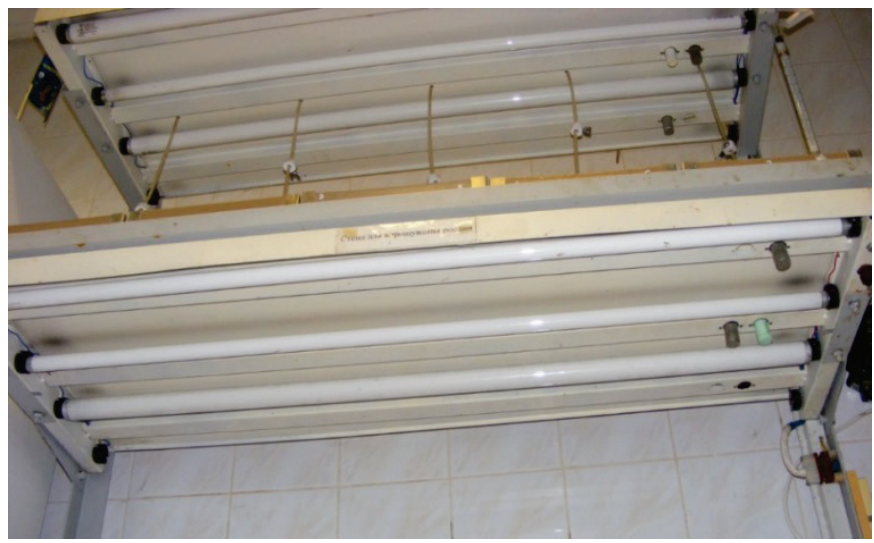

Рисунок 3. Оборудование для досвечивании растений на лабораторноэкспериментальной установке, на которой проводилась выгонка лука на перо

Шлам биогазовых производств получался в результате метанового сбраживания в термофильном режиме $\left(50^{\circ} \mathrm{C}\right)$ разбавленной водой твердой фракции навоза КРС до влажности 92\% на лабораторной биогазовой установке с объемом метантенка 30 л (рис. 4). Время сбраживания составляло 25 суток.

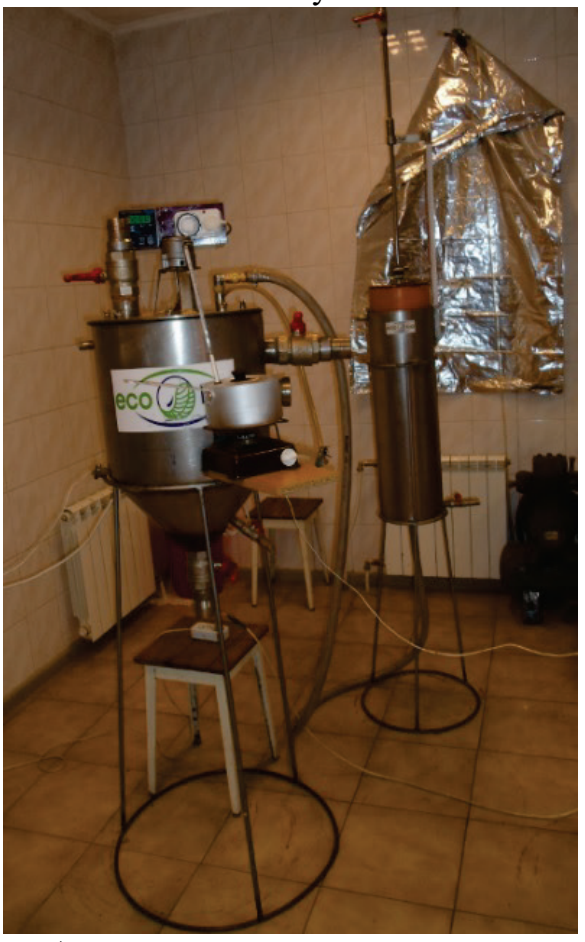

Рисунок 4. Лабораторная биогазовая установка 
Impact of sediment formed...

Шлам биогазовых производств заливался в емкость, где происходило его отстаивание в течение недели. После этого жидкая фракция сливалась. Отделение жидкой фракции от осадка контролировалось визуально.

Методика закладки опытов определения урожайности лука на перо. В грядку на грунт, согласно варианту опыта, высаживались по семь луковиц (рис. 5), которые ежедневно поливались чистой жидкой фракцией биошлама и ее смесью с водой в различных концентрациях (рис. 6). Для контроля проводились варианты исследований при поливе растения раствором минеральных удобрений (аммиачной селитрой) и чистой водой. На 7 растений выливалось 100 мл жидкости. Варианты опытов приведены в табл. 1.

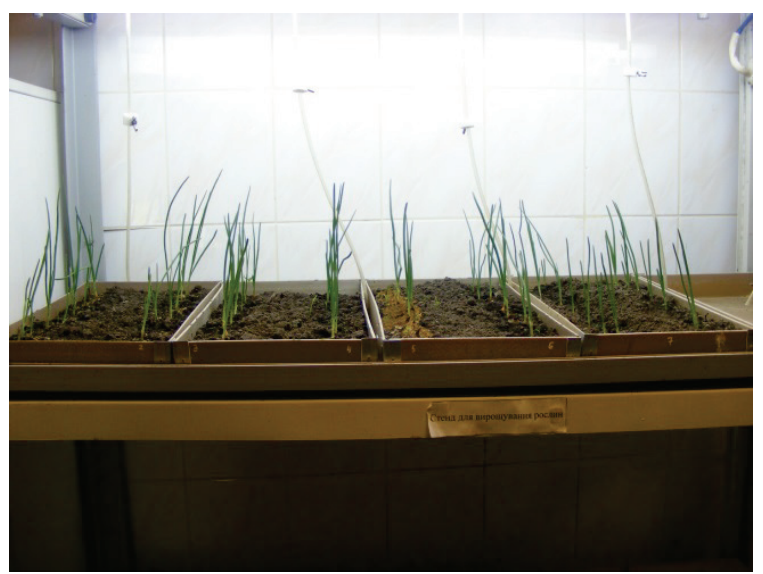

Рисунок 5. Заложенные опыты выращивания лука на перо

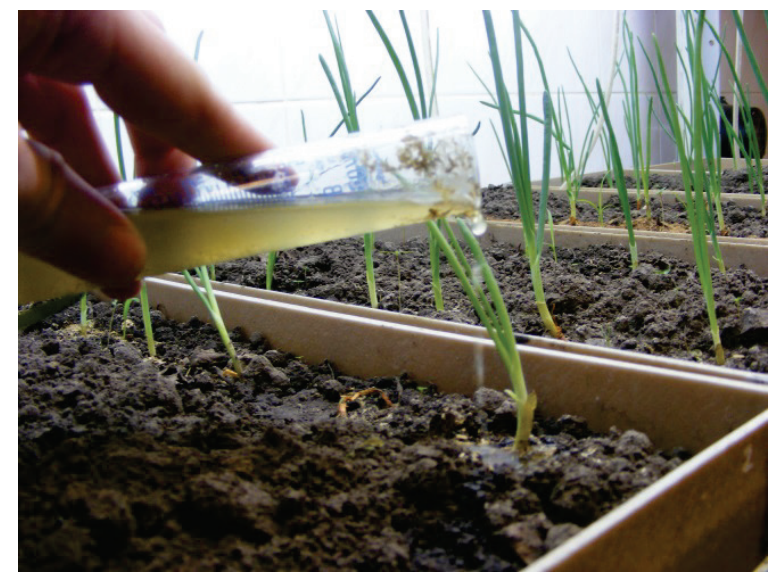

Рисунок 6. Полив лука водным раствором шлама биогазовых производств 
W. Romaniuk, V. Polishchuk, A. Marczuk, L. Titova, I. Rogovskii, K. Borek

Таблица 1

Варианты опытов определения влияния жидкой фракиии илама биогазовых установок на урожайность выращивания лука на перо и экологичность урожая

\begin{tabular}{cl}
\hline Номер & \multicolumn{1}{c}{ Вариант } \\
\hline 1 & Смесь жидкой фракции биошлама с водой в концентрации 1:500 \\
2 & Смесь жидкой фракции биошлама с водой в концентрации 1:100 \\
3 & Смесь жидкой фракции биошлама с водой в концентрации 1:50 \\
4 & Смесь жидкой фракции биошлама с водой в концентрации 1:10 \\
5 & Чистая жидкая фракция биошлама \\
6 & Минеральные удобрения (раствор в воде аммиачной селитры концентрацией 1:25) \\
7 & Чистая вода \\
\hline
\end{tabular}

Измерение высоты пера лука осуществлялось с помощью линейки (рис. 7), определения его массы - весами AD 1000.

Результаты определения урожайности лука на перо. При подкормке растений чистой жидкой фракцией биошлама четыре растения из семи погибли. В других вариантах опытов гибели растений не наблюдалось. Наибольшая средняя высота растений на седьмые сутки выращивания отмечалась при подкормке смесью жидкой фракции биошлама с водой в концентрации 1:50-1:500 и раствором минеральных удобрений и колебалась в пределах 19-21,5см, хотя высота отдельных растений достигала $27 \mathrm{~cm}$. Следует отметить, что при подкормке чистой жидкой фракцией биошлама высота отдельных растений, которые не погибли, составляла 23cм. Высота лука на перо на седьмые сутки выращивания приведена в табл. 2.

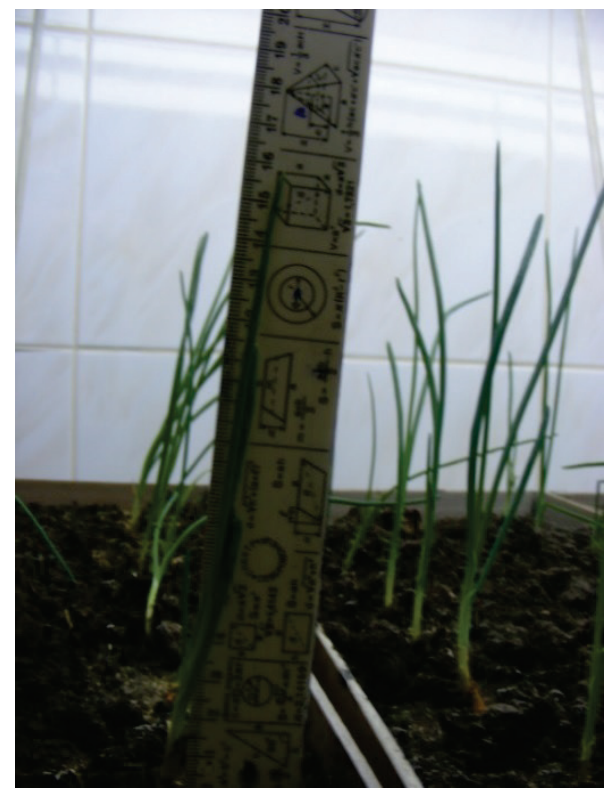

Рисунок 7. Измерение высоты перьев лука 
Impact of sediment formed...

Таблица 2

Высота лука-перо на седьмые сутки выращивания (в сантиметрах)

\begin{tabular}{lccccccc}
\hline Номер & \multicolumn{7}{c}{ Вариант опыта } \\
\cline { 2 - 7 } растения & №1 & №2 & №3 & №4 & №5 & №6 & №7 \\
\hline I & 22,0 & 18,0 & 15,5 & 21,5 & 23,0 & 18,5 & 20,0 \\
II & 27,0 & 15,0 & 25,6 & 14,5 & 23,0 & 21,5 & 13,0 \\
III & 18,0 & 26,0 & 17,3 & 16,0 & 9,0 & 16,4 & 18,0 \\
IV & 24,0 & 19,0 & 15,5 & 26,6 & 23,0 & 23,0 & 19,0 \\
V & 23,0 & 26,5 & 18,0 & 14,5 & погибла & 22,0 & 19,0 \\
VI & 20,0 & 24,0 & 21,0 & 15,0 & погибла & 18,5 & 15,0 \\
VII & 17,5 & 5,0 & 24,5 & 17,0 & погибла & 27,5 & 13,5 \\
Среднее & 21,6 & 19,1 & 19,6 & 17,9 & 11,1 & 21,1 & 16,8 \\
\hline
\end{tabular}

Наименьший средний вес одного растения отмечался при поливе лука чистой водой - 0,86г, наибольший - 1,66г - при подкормке смесью жидкой фракции биошлама с водой концентрацией 1:500. В остальных случаях средний вес одного растения примерно одинаковый - 1,37-1,46г. Показатели среднего веса выращенного пера лука приведены в табл. 3.

Итак, наибольшая урожайность наблюдалась при подкормке растений смесью жидкой фракции биошлама с водой концентрацией 1:500. При увеличении концентрации жидкой фракции биошлама и подкормке растений водным раствором минеральных удобрений урожайность лука на перо несколько снижалась. Подкормка растений концентрированной жидкой фракцией биошлама приводила к частичной гибели растений и снижению урожая. При поливе растений чистой водой урожайность лука на перо по сравнению с вариантом подкормки растений смесью жидкой фракции биошлама с водой концентрацией 1:500 снижалась наполовину.

Таблица 3

Средний вес лука на перо на седьмые сутки выращчвания

\begin{tabular}{ccc}
\hline $\begin{array}{c}\text { Вариант } \\
\text { № }\end{array}$ & Суммарный вес пера & Средний вес одного растения \\
\hline 1 & $(г)$ & $($ г) \\
2 & 11,65 & 1,66 \\
3 & 10,26 & 1,46 \\
4 & 10,12 & 1,44 \\
5 & 9,62 & 1,37 \\
6 & 5,73 & 1,43 \\
7 & 9,8 & 1,4 \\
\end{tabular}

\section{Методика исследования содержания нитратов в пере выращенного лука}

Перо лука срезается у основания почвы (рис. 8), предварительно измельчается, после чего отбирается средняя проба массой 10г. 
W. Romaniuk, V. Polishchuk, A. Marczuk, L. Titova, I. Rogovskii, K. Borek

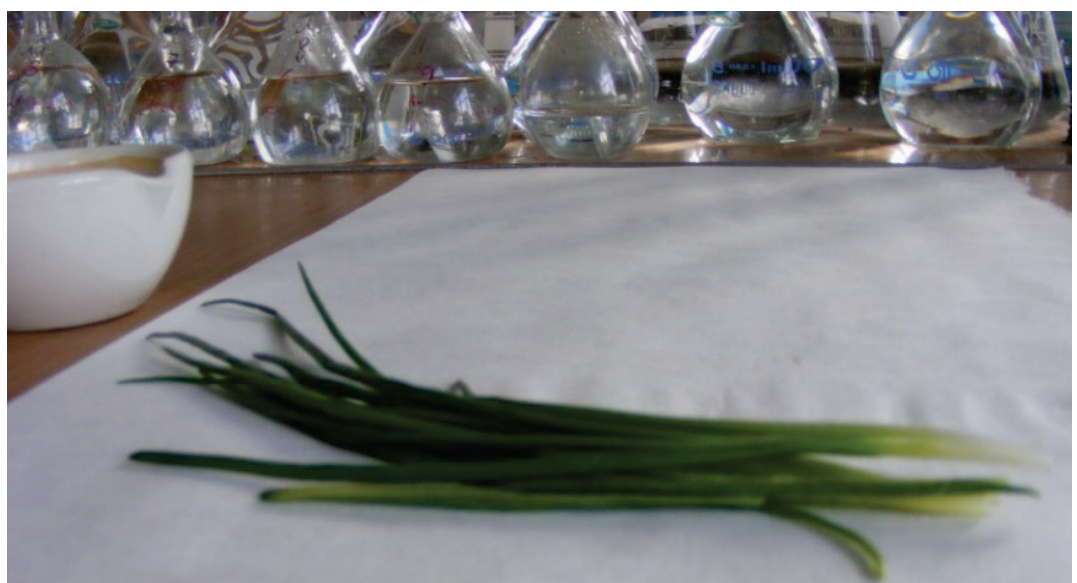

Рисунок 8. Срезанные перья лука, выращченные согласно одному из вариантов исследования

Навеска помещается в стакан гомогенизатора, доливается 50 мл 1\% раствора алюмокалиевых квасцов и гомогенизируется 1 мин. при перемешивании с частотой 6000 об./мин. После гомогенизации суспензия переносится в лабораторный стакан объемом 100 мл (рис. 9).

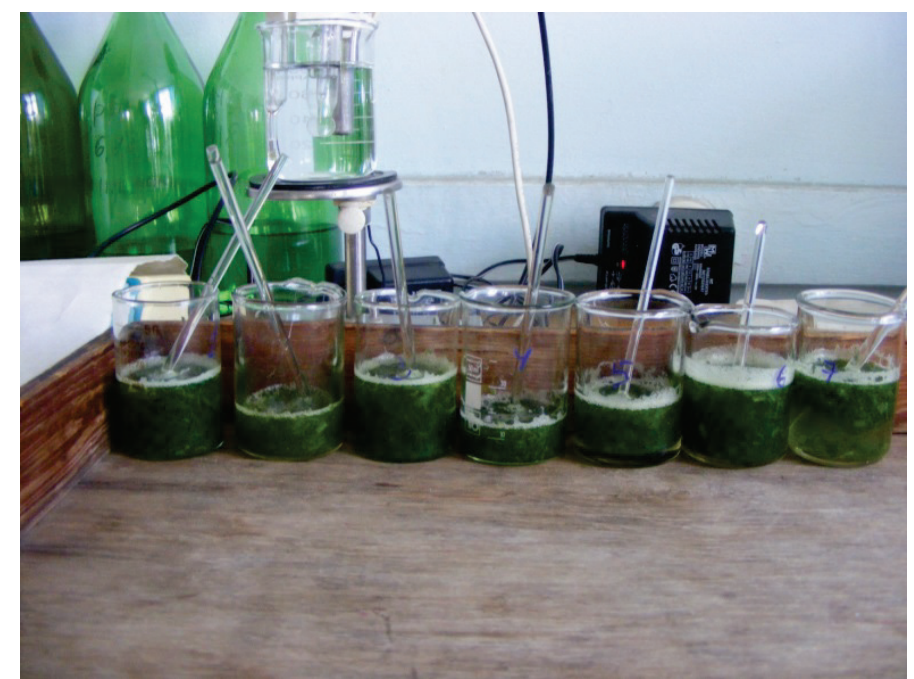

Рисунок 9. Суспензионная смесь перед проведением измерения на нитрать

Метод определения нитратов в продукции основан на извлечении нитратов из зеленых растений 1\%-ным раствором алюмокалиевых квасцов при отношении пробы в растворе 1:5 с последующим потенциометрическим определением их в солевой 
Impact of sediment formed...

суспензии с помощью ионоселективных электродов. Потенциометрический метод основан на измерении потенциала ионоселективного электрода, величина которого зависит от концентрации ионов, которые определяются в растворе. В качестве вспомогательного электрода используется насыщенный хлорсеребряный электрод. Измерение концентрации ионов $\mathrm{pNO}_{3}$ проводилось на ионометре $\mathrm{pX}-150.1 \mathrm{M} 1$ (рис. $10)$.

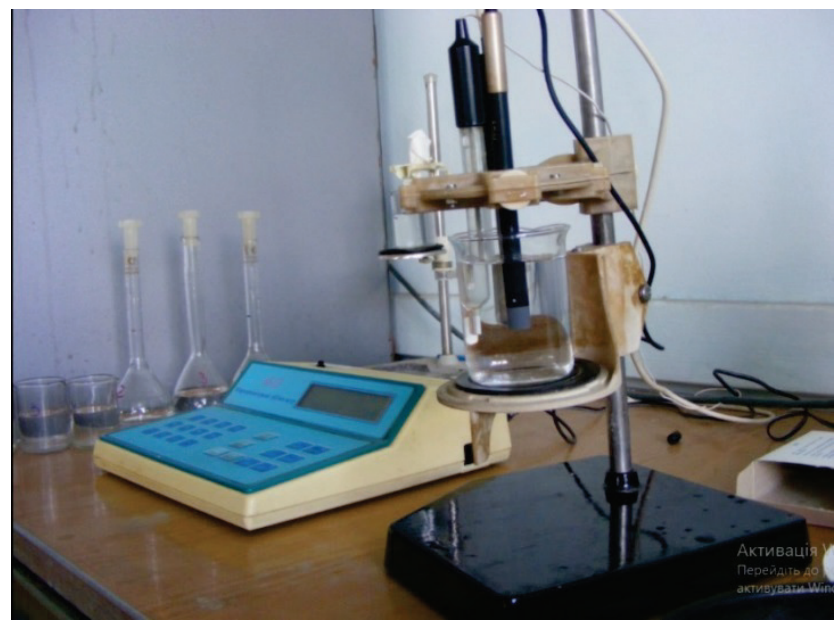

Рисунок 10. Ионометр рX-150.1M1

Перед измерением исследуемые пробы перемешиваются стеклянной палочкой (см. рис. 9), после чего в них опускаются электроды и проводятся измерения потенциала (через каждые 1,5-2 мин.). Размер $\mathrm{pNO}_{3}$ в пробах находится, используя градуировочный график, построенный на миллиметровой бумаге. По величине $\mathrm{pNO}_{3}$ в исследуемых пробах с помощью таблиц, приведенных в методических указаниях по определению нитратов и нитритов в продукции растениеводства (МУ 5048-89), определяется содержание нитратов.

Результаты определения содержания нитратов в выращенном луке на перо показаны в табл. 4.

Таблица 4.

Содержание нитратов в луке на перо

\begin{tabular}{ccc}
\hline Номер опыта & $\begin{array}{c}\text { Концентрация } \\
\mathrm{pNO}_{3}\end{array}$ & $\begin{array}{c}\text { Содержание нитратов } \\
\left(\mathrm{M \Gamma}^{*} \mathrm{~K}^{-1}\right)\end{array}$ \\
\hline 1 & 2,83 & 504,4 \\
2 & 2,67 & 729,1 \\
3 & 2,61 & 837,1 \\
4 & 2,49 & 1104 \\
5 & 2,39 & 1390 \\
6 & 1,85 & 4817 \\
7 & 2,71 & 664,9 \\
\hline
\end{tabular}


W. Romaniuk, V. Polishchuk, A. Marczuk, L. Titova, I. Rogovskii, K. Borek

Согласно табл. 4 можно отметить, что содержание нитратов в луке на перо растет с увеличением концентрации биошлама в растворе, который применяется для подкормки растений. Содержание нитратов в растениях не превышает ПДК (800 мг/кг для выращивания в закрытом грунте согласно СанПиН 42-123-4619-88) при ежедневной подпитке лука на перо раствором биошлама с концентрацией 1:1001:500. При концентрации биошлама в растворе более 1:50 содержание нитратов в луке на перо превышает ПДК, а при подкормке неразбавленной жидкой фракцией биошлама составляет 1390 мг'кร $\Gamma^{-1}$. Например, ежедневная подкормка растений азотными минеральными удобрениями приводит к концентрации нитратов в луке на перо 4817 мг'кГ $\Gamma^{-1}$, что в 5 раз превышает ПДК, поливка чистой водой -665 мг $к \Gamma^{-1}$.

\section{Выводы}

1. При почвенном выращивании лука на перо наибольшая урожайность наблюдается при подкормке смесью жидкой фракции шлама биогазовых производств с водой концентрацией 1:500. При увеличении концентрации жидкой фракции шлама биогазовых производств и подкормке растений водным раствором минеральных удобрений урожайность несколько уменьшается. Подкормка растений концентрированной жидкой фракцией шлама биогазовых производств приводит к частичной гибели растений и снижению урожая. При поливе растений чистой водой урожайность лука на перо по сравнению с вариантом подкормки растений смесью жидкой фракции шлама биогазовых производств с водой концентрацией 1:500 снижается наполовину.

2. Содержание нитратов в луке на перо не превышает ПДК при ежедневной подкормке растений смесью жидкой фракции шлама биогазовых производств с водой концентрацией 1:100-1:500. При увеличении концентрации жидкой фракции шлама биогазовых производств более 1:50 содержание нитратов в растениях превышает ПДК.

\section{Литература}

Mirel, I., Isacu, M., Bakos, M. (2012). Harnessing the untapped renewable energy potential of the organic loads of urban wastewater. 12th International Multidisciplinary Scientific Geoconference, SGEM, Albena, Bulgaria, IV, 515-522. doi:10.1109/iembs.2011.6090487.

Tambone, F., Scaglia, B., D'Imporzano, G., Schievano, A, Orzi, V., Salati, S., Adani, F. (2010). Assessing amendment and fertilizing properties of digestates from anaerobic digestion through a comparative study with digested sludge and compost. Chemosphere, 81(8). 577-583. doi: 10.1016/j.chemosphere.2010.08.034.

Sahlstrom, L. (2003). A review of survival of pathogenic bacteria in organic waste used in biogas plants. Bioresource technology, 87(2), 161-166. doi: 10.1016/S0960-8524(02)00168-2.

Kuusik, A., Pachel, K., Kuusik A., Loigu, E. (2017). Possible agricultural use of digestate. Proceedings of the Estonian academy of sciences, 66(1), 64-74. doi: 10.3176/proc.2017.1.10. 
Impact of sediment formed...

Bonetta, Sil., Bonetta Sara, Ferretti E., Fezia G., Gilli G., Carraro E. (2014). Agricultural Reuse of the Digestate from Anaerobic Co-Digestion of Organic Waste: Microbiological Contamination, Metal Hazards and Fertilizing Performance. Water air and soil pollution, 225(8). №2046. doi: 10.1007/s11270-014-2046-2.

Pampillon-Gonzalez, L., Luna-Guid, M., Ruiz-Valdiviezo, M., Franco-Hernandez, O., FernandezLuqueno, F., Paredes-Lopez, O., Hernandez, G., Dendooven, L. (2017). Greenhouse Gas Emissions and Growth of Wheat Cultivated in Soil Amended with Digestatefrom Biogas Production. Pedosphere, 27(2), 318-327. doi: 10.1016/S1002-0160(17)60319-9.

Pecharaply, A., Parkpian, P., Annachhatre, A.P., Jugsujinda, A. (2007). Influence of anaerobic codigestion of sewage and brewery sludges on biogas production and sludge quality. Journal of environmental science and health part a-toxic/hazardous substances \& environmental engineering, 42(7), 911-923. doi: 10.1080/10934520701369818.

Hai, D.M., Qiu, X., Xu, H., Honda, M., Yabe, M., Kadokami, K., Shimasaki, Y., Oshima, Y. (2017). Contaminants in Liquid Organic Fertilizers Used for Agriculture in Japan. Bulletin of environmental contamination and toxicology, 99(1), 131-137. doi: 10.1007/s00128-017-2081-y.

Suominen, K., Verta, M., Marttinen S. (2014). Hazardous organic compounds in biogas plant end products-Soil burden and risk to food safety. Scince of the total environment. 491 (Special Issue). 192-199. doi: 10.1016/j.scitotenv.2014.02.036.

Bayle, S., Cariou, S., Despres, J.-F., Chaignaud, M., Cadiere, A., Martinez, C., Roig, B., Fanlo, J.-L. (2016). Biological and Chemical Atmospheric Emissions of the Biogas Industry. 5th International conference on environmental odour monitoring \& control, NOSE 2016, Ischia, Italy. Chemical Engineering Transactions, 54. 295-300. doi: 10.3303/CET1654050.

Al Seadi, T., Drosg, B., Fuchs, W., Rutz, D., Janssen, R. (2013). Biogas digestate quality and utilization. Biogas handbook: science, production and applications. 5. 267-301. doi: 10.1533/9780857097415. 2.267.

Czekala, W., Dach, J., Dong, R., Janczak, D., Malinska, K., Jozwiakowski, K., Smurzynska, A., Cieslik, M. (2017). Composting potential of the solid fraction of digested pulp produced by a biogas plant. Biosystems engineering, 160. 25-29. doi: 10.1016/j.biosystemseng.2017.05.003.

Stefaniuk, M., Bartminski, P., Rozylo, K., Debicki, R., Oleszczuk, P. (2015). Ecotoxicological assessment of residues from different biogas production plants used as fertilizer for soil. Journal of hazardous materials, 298. 195-202. doi: 10.1016/j.jhazmat.2015.05.026.

Nicoletto, C., Santagata, S., Zanin, G., Sambo, P. (2014). Effect of the anaerobic digestion residues use on lettuce yield and quality. Scientia horticulturae. 180. 207-213. doi: 10.1016/j.scienta.2014. 10.028.

Odlare, M., Arthurson, V., Pell, M., Svensson, K., Nehrenheim, E., Abubaker, J. (2011). Land application of organic waste - Effects on the soil ecosystem. Applied Energy, 88(6), 2210-2218. doi: 10.1016/j.apenergy.2010.12.043.

Odlare, M., Lindmark, J., Ericsson, A., Pell, M. (2015). Use of organic wastes in agriculture. 7th International Conference on Applied Energy (ICAE), 2015, Abu Dhabi, U Arab Emirates. Clean, efficient and affordable energy for a sustainable future. 75. 2472-2476. doi: 10.1016/j.egypro.2015.07.225.

Nabel, M., Schrey, S.D., Poorter, H., Koller, R., Jablonowski, N.D. (2017). Effects of digestate fertilization on Sida hermaphrodita: Boosting biomass yields on marginal soils by increasing soil fertility. Biomass \& Bioenergy, 107. 207-213. doi: 10.1016/j.biombioe.2017.10.009. 
Muller-Stover, D.S., Sun, G., Kroff, P., Thomsen, S.T., Hauggaard-Nielsen, H. (2016). Anaerobic codigestion of perennials: Methane potential and digestate nitrogen fertilizer value. Journal of plant nutrition and soil science, 179(6), 696-704. doi: 10.1002/jpln.201500599.

Rozylo, K., Gawlik-Dziki, U., Swieca, M., Rozylo, R., Palys, E. (2016). Winter wheat fertilized with biogas residue and mining waste: yielding and the quality of grain. Journal of the science of food and agriculture, 96(10), 3454-3461. doi: 10.1002/jsfa.7528.

Garg, R.N., Pathak, H., Das, D.K., Tomar, R.K. (2005). Use of flyash and biogas slurry for improving wheat yield and physical properties of soil. Environmental Monitoring and Assessment, 102(1-3), 1-9. doi: 10.1007/s10661-005-2021-x.

Svensson, K., Odlare, M., Pell, M. (2004). The fertilizing effect of compost and biogas residues from source separated household waste. The Journal of Agricultural Science, 142(4), 461-467. doi: $10.1017 /$ S0021859604004514.

Kocar, G. (2008). Anaerobic digesters: from waste to energy crops as an alternative energy source. Energy Sources, Part A: Recovery, Utilization, and Environmental Effects. 30. 660-669. doi: 10.1080/00908310600628404.

Båth, B., Rämert, B. (1999). Organic Household Wastes as a Nitrogen Source in Leek Production. Acta Agriculturae Scandinavica, Section B - Soil \& Plant Science, 49(2), 201-208. doi: 10.1080/ 713782027.

Rivard C.J., Rodriguez, J.B., Nagle, N.J., Self, J.R., Kay, B.D., Soltanpour, P.N., Nieves, R.A. (1995). Anaerobic digestion of municipal solid waste. Applied Biochemistry and Biotechnology, 51. 125-135. doi: 10.1007/BF02933417.

Montemurro, F., Canali, S., Convertini, G., Vitti C. (2008). Anaerobic digestates application on fodder crops: effects on plant and soil. 25th National Congress of the Societa-Italiana-diChimica-Agraria, Pisa, Italy. Agrochemica. 52, 297-312.

Wentzel, S., Joergensen, R.G. (2016). Effects of biogas and raw slurries on grass growth and soil microbial indices. Journal of plant nutrition and soil science, 179(2), 215-222. doi: 10.1002/jpln. 201400544.

Simeckova, J., Elbl, J., Kintl, A. (2016). Changes in content of soil mineral nitrogen and utilization of mineral nitrogen by soil microorganusms due to application of different fertilizers. 23rd International PhD Students Conference (MendelNet), 9-10 November, 2016, Mendel Univ Brno, Fac AgriSciences, Brno, Czech Republic, 486-491.

Neves, A.C., Bergamini, C.N., Leonardo R. de O., Goncalves, M.P., Zenatti, D.C., Hermes, E. (2017). Effect of biofertilizer obtained by anaerobic digestion of cassava effluent on the development of crambe plants. Revista Brasiliera de engenharia agricola e ambiental, 21(10), 681-685. doi: 10.1590/1807-1929/agriambi.v21n10p681-685. 
Impact of sediment formed...

\title{
WPLYW OSADU POWSTAJĄCEGO PODCZAS PRODUKCJI BIOGAZU NA PRODUKTYWNOŚĆ UPRAWY I EKOLOGICZNOŚC PRODUKCJI UPRAWY CEBULI NA SZCZYPIOREK
}

\begin{abstract}
Streszczenie. Frakcja stała, zgodnie z wieloma badaniami, jest skutecznym nawozem organicznym, którego działanie jest na poziomie nawozów mineralnych, a nawet przewyższa ich efektywność, podczas gdy używanie frakcji płynnej nie zawsze daje pozytywne wyniki. Nie określono jednak, które dokładnie stężenia frakcji płynnej pofermentu po zastosowaniu jako nawóz organiczny dały wynik ujemny lub dodatni. W związku z tym, w artykule ustalono optymalne stężenie frakcji płynnej $\mathrm{w}$ wodnym roztworze do nawożenia roślin podczas uprawy cebuli na szczypiorek w glebie. Osad $\mathrm{z}$ produkcji biogazu otrzymano przy termofilnej fermentacji $\left(50^{\circ} \mathrm{C}\right)$ obornika bydlęcego $\mathrm{w}$ zakładzie laboratoryjnym, który działał przy okresowym reżimie załadunku. Czas fermentacji wynosił 25 dni. Oceniono siedem wariantów żywienia roślin: czysta woda (kontrola), nawozy mineralne (roztwór azotanu amonu w wodzie o koncentracji 1:25), nierozcieńczoną ciekłą frakcję biopaliwową i mieszaninę ciekłej frakcji z pofermentu z woda w stężeniach 1:10, 1:50, 1:100, 1:500. Ustalono, że najwyższa wydajność zaobserwowano przy nawożeniu roślin mieszaniną ciekłej frakcji z pofermentu o stężeniu 1:500. Wraz ze wzrostem stężenia płynnej frakcji i nawożeniem roślin wodnym roztworem nawozów mineralnych, wydajność cebuli nieco spadła. Nawożenie roślin stężoną frakcją ciekłą z pofermentu spowodowało częściową śmierć roślin i spadek wydajności. Kontrola uprawy na zawartość azotanów wykazała, że przy codziennym podlewaniu cebuli czystą wodą i mieszaniną ciekłej frakcji o stężeniu wody 1:100-1:500, nie przekroczono maksymalnego, dopuszczalnego stężenia (PDK), które wynosi $800 \mathrm{mg} \cdot \mathrm{kg}^{-1}$. W związku z tym, w przypadku uprawy cebuli na szczypiorek, biorąc pod uwagę wzrost plonu i niską zawartość azotanów, zaleca się stosowanie mieszaniny frakcji płynnej z wodą o stężeniu 1:500.
\end{abstract}

Słowa kluczowe: biogaz, biogazownia, bioszlam, szlam z biogazowni, nawozy organiczne, cebula na szczypiorek, produktywność, azotany, stężenie 